\title{
The Inquiry on the Necessity of Cultivating the Craftsman' spirit and the Cultivation Mode in Marine Vocational Education
}

\author{
Guangli Ren \\ Department of Navigational Technology, Tianjin Maritime College, Tianjin, 300350, China \\ rrggll@163.com
}

Keywords: Marine, vocational education, craftsman's spirit, cultivation

\begin{abstract}
Craftsman's spirit" was formally put forward by Premier Li Keqiang in the government work report of 2016, which shows that our country is desperate for "craftsman spirit". The connotation of the "craftsman's spirit" is introduced and then the necessity of cultivating the "craftsman's spirit" is illustrated on the basis of the connotation of the "craftsman's spirit", finally the cultivation mode of "craftsman's spirit" is studied in this paper.
\end{abstract}

\section{Introduction}

Although there is no clear definition of the "craftsman's spirit", the essential part of the "craftsman's spirit" and its outstanding characteristics are to seek for greater perfection. "Craftsman's spirit" is referred to as seeking for greater perfection in Premier Li Keqiang's government work report. We should not only draw our attention on seeking for greater perfection, but also should draw our attention on the core essence of seeking for greater perfection to explore the deeper connotation of "craftsman's spirit" because we are doing academic research. In general, the "craftsman's spirit" is to strive for excellence in quality and service, and to make great improvement diligently for innovation [1].

\section{The Connotation and Origin of the "Craftsman's spirit"}

Seeking for Greater Perfection. Craftsmanship is the essence of survival in every trade. Only paying attention to detail, striving for perfection and perfection, not satisfying $99 \%$ but diligently pursuing $100 \%$ can make great improvement.

Rigorous and Meticulous. Regarding quality as life, not be opportunistic, making sure that every component is qualified, and adopting strict inspection standard can ensure everything goes well.

Patience, Focus and Persistence. There is no best one, only better and better one in product quality and service quality, because the real craftsmen will never stop their footsteps to pursue perfection in both the performance of the product and service details. Only concentrating in one thing can make it extremely perfect.

"Craftsman's spirit". When "craftsman's spirit" is referred to, most people think of German and Japan which are good at industry. But the "craftsman's spirit" can be found in every country with historical accumulation. "Craftsman's spirit" has been recorded since ancient times in China such as dynasty Xia and Shang. The craftsmen in ancient china have good artificial skill and can make various products which have various functions. But "craftsman's spirit" declined in modern times of China because of the historical reason. So we must advocate pick up "craftsman's spirit" vigorously.

Professional and Dedicated. The "craftsman's spirit" is to pursue the top level of the industry, to provide the most excellent products and the best service in the industry [2].

Indifferent to Fame and Wealth. A good craftsman will work intently at all times. His motivation is not money, not fame, but the enthusiasm coming from the deeply soul. The only thing they are chasing is to handle things to the extreme perfection. 


\section{The Necessity of Cultivating "Craftsman’s spirit" in Marine Vocational Education}

To Build a Maritime Power Requires Seafarers with "Craftsman's spirit". The report of the 18th national congress of the communist party of China (CPC) pointed out that "the development and utilization of Marine resources should be further strengthened; the country's maritime rights and interests will be firmly safeguarded; and the maritime power will be built". It is the first time that the goal of "building a maritime power" formally made. This great goal indicates that China's maritime strategy has risen from building a "big maritime country" to building a "strong maritime country". At present, China is a big maritime country, but not a strong maritime country. Our Party has made clear the goal of "building a strong maritime country" in the government work report of the 18th national congress of China. In order to build a "strong maritime country", the high-end sea talents are indispensable human resource factors, and further more a large number of seafarers with "craftsman's spirit" are an important part of human resources [3-4]. Cultivating the "craftsman's spirit" in teaching process is an indispensable part of education.

The Structural Reform of Supply Side in the Seafarers' market Needs the "Craftsman's spirit" Seafarers. Seafarers belong to the labor force on the supply side. It is the manpower that guarantee for the safe production of ships and the normal operation of the enterprises. The industry innovation and the inheritance of skills are not available without the support of seafarers. The low quality of seafarer's service supply, low service level and low professional loyalty are the main problems. The government's structural reform of supply side is an important innovation of new economic normality. It also has the significance of being weathervane as China's Seamen's labor market system reform [1]. The sluggish shipping market has put a lot of pressure on the seafarers' market in recent years. China's seafarer market is oversupplied in quantity, but the seafarers with advanced technical ability and skilled seamanship are still in serious shortage. Many seafarer especially young seafarers are lack of experience, manipulative ability, emergence handling ability. The investigation found that most maritime colleges draw their attention mainly on how to increase the competency certificate passing rate of the students. They emphasis on examination-oriented education and ignore the cultivation of "craftsman's spirit", which leads to the graduates cannot quickly adapt the work onboard the vessel. The result is graduates cannot work onboard vessel because of lack of skill and experience. On the other side, enterprises cannot find the proper graduates because the students cannot be competent for their job. How to resolve this problem? The supply-side structural reform that is now actively implementing in China provides solutions for us. Seafarer market must carry out structural adjustment, reduce the supply of the low end, improve the supply of high-end, to cultivate the "craftsman's spirit" of the students in maritime vocational education.

The Survival and Development of Shipping Companies can not be Achieved without the Seafarers with “Craftsman's spirit”. The development of enterprises requires the “craftsman's spirit". The strength of the shipping enterprise competitiveness depends on not only a total of manpower and material resources, but also the core enterprise spirit which can hand down hundreds years. With the promotion of science and technology, shipping companies will develop toward the direction of specialization and detailed division of labor. When the companies select talents, they will pay more attention on whether the talents fit their corporate culture, whether the talents meet the specific requirements of the enterprise special jobs. The global economy recovers so sluggish today, the competition in the shipping market is more and more severe. Shipping companies must cultivate enterprise's core competitiveness, must build a brand with "craftsman's spirit". Professional crew team which can guarantee the fierce competition of the company is the best signature of shipping enterprise.

The Cultivation of the "Craftsman's spirit" of the Students can Improve the Competitiveness of the Maritime Colleges. It is necessary for the maritime universities to focus on the talent demand of the enterprises, especially maritime vocational colleges, which are oriented by the market and students' employment [5]. Most executives think that the experience, knowledge and ability can be gradually developed in the working practice, but individual character, sense of responsibility, dedication, meticulous work attitude and other basic quality must start from the 
school culture and formed step by step. Therefore, in the process of teaching students' professional knowledge, the school should pay close attention to the shaping and cultivation of the "craftsman's spirit” of the students. It is also necessary to strengthen the cultivation of students' vocational spirit. The social recognition of the graduated students can indicate a school's talent training level. The graduated students realize their own development and show self-worth at the same time. In turn, this will strengthen the competitiveness and reputation of the school they graduated from. At the same time, the existence and development of maritime college and the realization of the student value are both guaranteed. Maritime vocational colleges should grasp the pulse of the economic development. Under the background of more rapidly updated technology, the industrial transformation and upgrading, the economic development power has been changed from elements driving to innovation driving. Therefore, future talent training mode should also be in accordance with this tendency.

The "Craftsman's spirit" is the Footstone of Employment, Growth and Development of Students. The “craftsman's spirit”, personally, can be regarded as a kind of meticulous and dedicated professional spirit. With the "craftsman's spirit”, people don't take jobs as an equipment of raising family, but as a tool to realize self-worth. Thus they treat work with the heart of proud. Each seafarer, especially the new graduates who are prepared to become a seafarer must have the “craftsman's spirit". To ensure ship maintenance is carried out delicately; each voyage task is done perfectly; seamanship is done as art other than skills are the performance of "craftsman's spirit”. Instead of being limited to the promotion from the rating to the senior crew, the career plan is designed to a higher standard of the career [1]. Only in this way can seafarers provide the most powerful support for the ship owners. Only in this way can seafarers provide the best service for the employer. Only in this way can seafarers make a great career in the shipping position.

\section{The Mode to Cultivate "Craftsman's spirit” of the Students in Maritime Profession Education}

As a seafaring artisan, it is necessary to bring the meticulous and refined professional spirit to every corner of the work so as to provide the first-class service and give the other persons a very good work feeling. How to make maritime vocational college students get such valuable professional spirit? This will inevitably require maritime vocational colleges reform the current vocational education system thoroughly, e.g. to pay attention to build a teacher team of double-qualification and to reform the corresponding curriculum system systematically. Maritime vocational colleges have to introduce modern apprenticeship and enhance the cooperation between the college and the enterprises. Maritime vocational colleges must do more to let the "craftsman's spirit" generate, grow and inherit.

Integrate the Cultivation of "Craftsman's spirit" into the Teaching of the Specialized Courses. The instructor should first systematic analyze the professional knowledge and professional quality of the students in navigation major. The instructor should also summarize teaching methods which can teach professional knowledge and cultivate professional spirit and then apply these methods into daily professional course teaching. In this way, students will be able to absorb and digest the knowledge of navigation and meanwhile form "craftsman's spirit" which is shown as patience concentration, profession and diligent. Teachers who teach specialized courses should behave as a model for the students to carry out "craftsman's spirit" so that the teaching effect can be improved rapidly. In the course of daily teaching, teachers should be as a model for students to learn, which can improve the actual teaching effect to a great extent.

Practice is an Important Way to Cultivate the "Craftsman's spirit" of the Students. The cultivation and formation of "craftsman's spirit" depend not only on theoretical education, but also on working practice. In the working practice, professionalism has the opportunity to develop into professional quality. Students can truly understand the connotation of "craftsman's spirit" in working practice and consider the "craftsman's spirit" as the vocational objective and practice the "craftsman's spirit" in working process. Practice education can be performed in a simulated work environment or during a cognitive internship. The BRM course adopts an advanced teaching method based on the former. First establish simulation of real working environment, and then let the 
students do the professional practical operation. The teachers give the students on scene instruction to pass the rigorous, careful, meticulous attentive "craftsman's spirit" to the students.

The Cooperation of School and Enterprises is an Effective Platform to Cultivate the "Craftsman's spirit". The mixture between colleges and enterprise culture is an important part of the mainstream soft power cooperation between colleges and enterprise. Making the enterprise culture mixed with the college culture through various paths and then enterprise culture will influence the campus culture. Thus campus culture and enterprise culture will promote each other and mutually fuse with each other. Maritime vocational college culture and shipping companies has some difference and also have some common parts. They can use the college-enterprise cooperation as a platform to coordinate and develop each other. It is the common goal of the campus and the shipping companies to cultivate excellent craftsmen. Campus culture and corporate culture is a junction to cultivate vocational quality, to utilize the comprehensive ability and to develop the potential value of people. This junction can change the students from college to seafarer craftsmen and also can strengthen the integration of school-enterprise culture. So we should create the environment of cultivating "craftsman's spirit" and build a platform to cultivate "craftsman's spirit".

The Modern Apprenticeship System is the Effective Means of Cultivating the "Craftsman's spirit". At present, the vocational colleges are exploring the training mode of modern apprenticeship. Students following teacher in working practice is an effective mode to strengthen the manipulative ability and practice ability. This mode is conformal with the "craftsman's spirit" and is by far the most scientific and efficient training method. The modern apprenticeship system focuses on cultivating the professional and technical ability, and furthermore pays more attention to the instructing, helping and leading effect of the teacher. The most professional skill of the crew is taught by experienced personnel in the actual work environment. Professionalism and career ethics are obtained by teacher's modal effect. The captain let the students learn technical skills, develop meticulous attentive and seeking for greater perfection work attitude, which is exactly the same as the connation of "craftsman's spirit" [3][5].

\section{Conclusion}

To sum up, the "craftsman's spirit" is the soul of maritime vocational education. Firstly, vocational colleges and enterprises should make joint efforts to improve the modern vocational education system, energetically develop advanced skills talents, and enhance the cooperation between colleges and enterprises. Vocational colleges and enterprises should also make the students master the theoretical knowledge in school, accept the influence of the enterprise culture and enterprise spirit in the practice and eventually combine the behavior and knowledge. Secondly, we should establish and improve the training mode of modern apprenticeship on the basis of college-enterprise cooperation, and integrate the cultivation of the "craftsman's spirit" into the daily teaching. In addition, we are in urgent need to strengthen the top-level design, to build the atmosphere for the whole society to respect career, labor. We should respect craftsmen, let them work decently. The craftsman will become the idol in vocational college students mind. We should ensure that the craftsmen are not trapped by basic livelihood so that they can develop their skill in practice with great concentration. Only in this way can they become "the craftsmen in great power" of highly charm, meanwhile, this is our nation's hope.

\section{References}

[1] Chi Yi. The research on methods and tactics of promoting the "craftsman's spirit" into vocational education [J]. Education teaching forum, 2017, 34:127-128.

[2] Deng Cheng. How to develop the craftsman's spirit in modern vocational education [J]. Contemporary vocational education, 2014, 10:91-93.

[3] Wang Ting, Research on the promotion approach to integrate "artisan spirit" into training system of quality education in vocational colleges [J]. Technology outlook, 2017, 4:25-28. 
[4] Kong Baogen. The practice methods of cultivating "craftsman's spirit" in vocational colleges [J]. Journal of NingBo university (education science edition), 2016, 3:88-90.

[5] Yang Hongquan and Su Wei. Research on the cultivation of contemporary artisan spirit based on modern apprenticeship [J]. Knowledge economy, 2016, 16 edition: 27-32. 